\title{
Regulatory Disclosure of Large Business Groups in Korea
}

\author{
Jae-Hyun GWON*
}

Received: September 14, 2019 Revised: November 03, 2019 Accepted: January 05, 2020

\begin{abstract}
Purpose: This paper examines the theoretical grounds for the disclosure of the Korea Fair Trade Commission. Three central measures of the disclosure are scrutinized: The interconnected status of affiliate companies, the important matters of private affiliates, and the large internal transactions. Contemplating on three measures, respectively, we review the rationale and derive policy implications. Research design, data, and methodology: Collecting the data of violation rates and remedial measures, we analyze the intensity of the disclosure enforcement. These statistics are critically reviewed by the economic literature of mandatory disclosure. Results: Statistics evince that the Korea Fair Trade Commission has enforced the regulatory disclosure quite successfully. Violation rates of the disclosure has declined from the outset. It demonstrates that the Korea Fair Trade Commission has enforced those measures satisfactorily for about a decade. But we cannot ascertain empirically whether the regulatory disclosures are socially and economically beneficial. To evaluate the effect of the regulatory disclosures precisely, we need a further empirical investigation. Conclusions: Despite the lack of policy evaluation, this study suggests complementary measures for current disclosures. First, disclosure of executive compensation in privately held subsidiaries must be introduced. Second, the controlling shareholder/manager should be responsible for information disclosure on foreign subsidiaries.
\end{abstract}

Keywords: Regulatory Disclosure, Business Groups, Tunneling

JEL Classification Code: K20, K42, L51

\section{Introduction}

In November 2018, the Korea Fair Trade Commission (KFTC) proposed to revise the Monopoly Regulation and Fair Trade Act (KFTA) entirely. Facing drastic changes in information technology, business environment, and industry structure, KFTC is challenged to amend the Act in accord. The draft of the revision had passed the Cabinet Council and, as of June 2019, it is under Parliamentary review.

Since the inception of the Act, KFTC has dealt with presumably harmful, economic concentration issues including monopoly problems. As for corrective or preventive purposes, the regulator mainly employs two policy tools: Antitrust measure and large business group

\footnotetext{
* Assistant Professor, School of Northeast Asian Studies, Incheon National University, South Korea [Postal Address: 119 Academy-ro, Yeonsu-gu, Incheon 22012, Republic of Korea].

Email: gwon@inu.ac.kr

(c) Copyright: Korean Distribution Science Association (KODISA)

This is an Open Access article distributed under the terms of the Creative Commons Attribution NonCommercial License (https://creativecommons.org/licenses/by-nc/4.0/) which permits unrestricted noncommercial use, distribution, and reproduction in any medium, provided the original work is properly cited.
}

regulation. The former is ubiquitous in most developed economies, while the latter is quite unique in South Korea. KFTC is primarily authorized to foster social welfare in command of pro-competitive policies. When the KFTA was enacted in the beginning, large business groups were thought to be a root of unfair, anti-competitive business practice. This antipathy made the KFTA introduce an extra regulation, beyond traditional anti-trust features, on large business groups (also known as chaebols).

KFTC's regulations on large business groups are classified by two types: Direct regulation and indirect regulation. Direct regulation refers to the ex-ante injunctions on corporate structure of the ownership and the control; whereas, indirect regulation pertains to the ex-post disclosure of important events. Table 1 lists the measures of direct and indirect regulations by KFTC.

A business group with combined total asset greater than or equal to KRW 5 trillion (approximately USD 4.28 billion) is defined as a 'large business group subject to the mandatory disclosure (disclosure group hereafter).' Every individual affiliate of a disclosure group should observe mandatory disclosure enforced by KFTC. First, a disclosure group must report the ownership/control network between 
subsidiary companies. Reported are the shares owned by the ultimate owner/controller, the owner/controller's family members, the controller's relatives, the controlled subsidiaries in effect, and the managers of the controlled subsidiaries. Second, it must reveal important corporate issues of privately held subsidiaries immediately. The disclosure should embrace major changes in corporate governance, merger and acquisition, sale of business, share exchange, and so forth. Third, a disclosure group must inform large internal transactions. Large internal transactions must be approved beforehand by the board of directors and they should be publicized immediately.

Table 1: Direct and indirect policy measures of KFTA

\begin{tabular}{|c|c|c|}
\hline Type & $\begin{array}{c}\text { Regulated Business } \\
\text { Groups }\end{array}$ & Regulatory Measure \\
\hline \multirow{3}{*}{ Indirect } & $\begin{array}{l}\text { Total assets } \geq \text { KRW } 5 \\
\text { trillion }\end{array}$ & Disclosure of the group status \\
\hline & Total assets $\geq$ KRW 5 trillion & $\begin{array}{l}\text { Disclosure of important } \\
\text { matters of private affiliates }\end{array}$ \\
\hline & Total assets $\geq$ KRW 5 trillion & $\begin{array}{l}\text { Disclosure of large internal } \\
\text { transactions }\end{array}$ \\
\hline \multirow{5}{*}{ Direct } & Total assets $\geq \mathrm{KRW} 5$ trillion & $\begin{array}{l}\text { Ban on the fraudulent pursuit } \\
\text { of family interest }\end{array}$ \\
\hline & $\begin{array}{l}\text { Total assets } \geq \text { KRW } 10 \\
\text { trillion }\end{array}$ & $\begin{array}{l}\text { Restriction on cross- } \\
\text { shareholding ownership }\end{array}$ \\
\hline & Total assets $\geq$ KRW 10 trillion & Restriction on debt guarantee \\
\hline & Total assets $\geq \mathrm{KRW} 10$ trillion & $\begin{array}{l}\text { Restriction on voting rights of } \\
\text { financial and insurance } \\
\text { subsidiaries }\end{array}$ \\
\hline & Total assets $\geq \mathrm{KRW} 10$ trillion & $\begin{array}{l}\text { Restrictions on the holding } \\
\text { company }\end{array}$ \\
\hline
\end{tabular}

Stricter regulations are added on larger business groups. KFTC places strict restrictions on the large business group with the total combined assets of more than or equal to KRW 10 trillion (approximately USD 8.56 billion). Given indirect disclosure regulation, this kind of large business group is additionally subject to direct regulation on crossshareholding ownership, debt guarantee, and exercise of voting rights of financial subsidiaries. Certain ownership structure is banned, and control rights are restricted conditionally. Since cross shareholding is prohibited, these business groups are named as 'large business groups with restricted cross shareholding (no crossholding groups hereafter).

This article focuses only on indirect regulations of the KFTC, which consist of three mandatory disclosure measures: The interconnected status of affiliate companies, the important matters of private affiliates, and the large internal transactions. We find that violation rates of the disclosure of the Korea Fair Trade Commission has declined from the outset. It demonstrates that the Korea
Fair Trade Commission has enforced those measures quite successfully for about a decade. But we cannot ascertain empirically whether the regulatory disclosures are socially and economically beneficial. To evaluate the regulatory disclosures fairly, we need further empirical investigation is needed. Despite the lack of policy evaluation, this study suggests complementary measures for current disclosures. First, disclosure of executive compensation in privately held subsidiaries must be introduced. Second, the controlling shareholder/manager should be responsible to disclose the information on foreign subsidiaries.

Section 2 summarizes how well the three measures have been enforced. Using KFTC's white papers, we quantitatively examine the observance of mandatory disclosure. Section 3 reviews the KFTC's mandatory disclosures from critical point of view. Pros and cons of the disclosure are addressed. Section 4 concludes what KFTC should consider in reforming current Fair Trade Act.

\section{Enforcement of the Disclosure by KFTA}

\subsection{Disclosure of the Business Group Status}

Through the electronic platform by the Financial Supervisory Service, the disclosure group should inform the group status comprehensively. The information is mainly about (1) general group status, (2) configuration of executives and directors, (3) stock ownership by various interest parties, and (4) transactions between the controllers and the subsidiaries.

Table 2: Enforcement of group status disclosure

\begin{tabular}{|c|c|c|c|c|}
\hline \multirow{2}{*}{$\begin{array}{c}\text { Year } \\
\text { (20xx) }\end{array}$} & \multirow{2}{*}{$\begin{array}{c}\text { Inspected } \\
\text { (companies } \\
\text { /groups) }\end{array}$} & \multirow{2}{*}{$\begin{array}{c}\text { Violation } \\
\text { (cases } \\
\text { /companies; } \\
\text { rate) }\end{array}$} & $\begin{array}{c}\text { Penalty } \\
\text { (KRW } \\
\text { mil.) }\end{array}$ & $\begin{array}{c}\text { Warning } \\
\text { (cases) }\end{array}$ \\
\hline 10 & $45 / 45$ & $\begin{array}{c}37 / 22 \\
(48.9 \%)\end{array}$ & - & 37 \\
\hline 11 & $284 / 9$ & $\begin{array}{c}195 / 119 \\
(41.9 \%)\end{array}$ & 149 & 127 \\
\hline 12 & $311 / 7$ & $\begin{array}{c}261 / 148 \\
(47.6 \%)\end{array}$ & 357 & 109 \\
\hline 13 & $367 / 19$ & $\begin{array}{c}353 / 181 \\
(49.3 \%)\end{array}$ & 340 & 163 \\
\hline 14 & $424 / 58$ & $\begin{array}{c}352 / 179 \\
(42.2 \%)\end{array}$ & 438 & 167 \\
\hline 15 & $397 / 60$ & $\begin{array}{c}316 / 143 \\
(36.0 \%)\end{array}$ & 611 & 104 \\
\hline 16 & $155 / 27$ & $\begin{array}{c}65 / 41 \\
(26.5 \%)\end{array}$ & 169 & 18 \\
\hline 17 & $297 / 20$ & $\begin{array}{c}8 / 7 \\
(2.4 \%)\end{array}$ & 295 & - \\
\hline
\end{tabular}

Source: Korea Fair Trade Commission, Fair Trade White Paper 2011-2018 
Table 2 shows the violation and the penalty since 2010 when this measure was implemented.

As shown in Table 2, the violation of group status disclosure has declined dramatically. Owing to the corrective measures of warnings and fines, large business groups are complying with the disclosure rule more precisely. As the compliance rate is improving, the KFTC is to reduce the burden of inspection by carrying out nonregular examinations on important matters rather than regular checkups.

Note 1: Violation rate is the number of violating companies out of inspected companies.

Note 2: The 2016 and 2017 statistics indicate a regular disclosure inspection only. Non-regular inspection in 2016 found 31 companies from 7 business groups, which charged 83 cases for fine worth 521 million Korean won and imposed warning for 19 cases. In 2017, non-regular inspection found 3 cases from 2 groups where 3 cases were fined by 12 million Korean won and 2 cases were warned.

\subsection{Disclosure of Privately Held Subsidiaries}

The disclosure groups are required to report some important matters of their privately held subsidiaries when the events happen. It is an international standard that publicly traded companies must obey strict disclosure rules by the Securities Act and the Exchange Act. However, in South Korea, the Fair Trade Act requests the disclosure groups to make public some additional information even on their private subsidiary firms. Disclosure of privately held subsidiaries is one of the most unique and strict features of the KFTA.

By the KFTA, important matters of privately held subsidiaries come under the following categories: (1) Changes in important matters pertinent to corporate governance such as ownership and control, (2) events that change financial structure significantly, and (3) events that impact on management activity to change significantly. Table 3 arranges the violations of this disclosure in time series.

Note 1: Violation rate is the number of violating companies out of inspected companies.

Note 2: The 2016 statistics indicate a regular disclosure inspection only. Non-regular inspection in 2016 found 4 companies from 1 business group, which charged 16 cases for a fine worth 109 million Korean won. In 2017, neither regular nor non-regular inspection was carried out.

From 2006 to 2009, the regulator drew the inspection samples randomly. During 2010-2014, it had examined top 42 business groups sequentially. Since 2014, KFTC randomly drew $1 / 4$ out of the disclosure groups. As shown in Table 3, the violation rate tended to fall so KFTC determined to skip examinations in 2017. It is because KFTC infers that large business groups conform well to the disclosure of privately held subsidiaries.

Table 3: Enforcement of the disclosure on the privately held subsidiaries

\begin{tabular}{|c|c|c|c|c|}
\hline \multirow{2}{*}{$\begin{array}{c}\text { Year } \\
\text { (20xx) }\end{array}$} & $\begin{array}{c}\text { Inspected } \\
\text { (companies/ } \\
\text { groups) }\end{array}$ & $\begin{array}{c}\text { Violation } \\
\text { (cases/ } \\
\text { companies; } \\
\text { rate) }\end{array}$ & $\begin{array}{c}\text { Penalty } \\
\text { (KRW } \\
\text { mil.; cases/ } \\
\text { companies) }\end{array}$ & $\begin{array}{c}\text { Warning } \\
\text { (cases/ } \\
\text { companies) }\end{array}$ \\
\hline 06 & $74 / 54$ & $\begin{array}{c}40 / 21 \\
(28.4 \%)\end{array}$ & - & $40 / 21$ \\
\hline 07 & $102 / 57$ & $\begin{array}{c}115 / 44 \\
(43.1 \%)\end{array}$ & $\begin{array}{c}118 \\
(19 / 9)\end{array}$ & $96 / 35$ \\
\hline 08 & $140 / 11$ & $\begin{array}{c}169 / 98 \\
(41.5 \%)\end{array}$ & $\begin{array}{c}1,118 \\
(153 / 91)\end{array}$ & $16 / 7$ \\
\hline 09 & $140 / 28$ & $\begin{array}{c}75 / 43 \\
(30.7 \%)\end{array}$ & $\begin{array}{c}180 \\
(39 / 29)\end{array}$ & $36 / 23$ \\
\hline 10 & $233 / 7$ & $\begin{array}{c}75 / 54 \\
(23.2 \%)\end{array}$ & $\begin{array}{c}132 \\
(34 / 29)\end{array}$ & $41 / 31$ \\
\hline 11 & $238 / 9$ & $\begin{array}{c}60 / 47 \\
(19.7 \%)\end{array}$ & 89 & $21 /-$ \\
\hline 12 & $248 / 7$ & $\begin{array}{c}76 / 54 \\
(21.8 \%)\end{array}$ & 178 & $21 /-$ \\
\hline 13 & $274 / 19$ & $\begin{array}{c}224 / 114 \\
(41.6 \%)\end{array}$ & 440 & $71 /-$ \\
\hline 14 & $330 / 58$ & $\begin{array}{c}123 / 74 \\
(22.4 \%)\end{array}$ & 193 & $42 /-$ \\
\hline 15 & $284 / 60$ & $\begin{array}{c}97 / 66 \\
(23.2 \%)\end{array}$ & 204 & $30 /-$ \\
\hline 16 & $75 / 27$ & $\begin{array}{c}34 / 16 \\
(21.3 \%)\end{array}$ & 50 & $7 /-$ \\
\hline
\end{tabular}

Source: Korea Fair Trade Commission, Fair Trade White Paper 2009-2018

\subsection{Disclosure of Large Internal Transactions}

Large internal transactions within the disclosure group must be approved by the board of directors beforehand. Afterwards the details of those internal transactions must be disclosed in no time. Disclosure of large internal transactions was introduced to make the board of directors hold responsible for corporate transactions. At the same time, it is hoped to support minor shareholders to monitor fraudulent resource transfers within a business group. This disclosure measure became effective from year 2002.

Table 4 displays the record of violations of large internal transactions disclosure.

From the outset of this disclosure measure, KFTC has inspected companies under suspicion while changing the target business groups by turns. From 2002 to 2010, KFTC enforced the disclosure of large internal transactions, while it held education sessions for compliance officers. Owing to steady inspection and compliance education, KFTC has moderated the violation of large internal transactions 
disclosure.

Table 4: Enforcement of large internal transactions disclosure

\begin{tabular}{|c|c|c|c|c|}
\hline $\begin{array}{l}\text { Year } \\
(20 x x)\end{array}$ & $\begin{array}{c}\text { Inspected } \\
\text { (companies/groups) }\end{array}$ & $\begin{array}{l}\text { Violators } \\
\text { (companies) }\end{array}$ & $\begin{array}{l}\text { Violations } \\
\text { (cases) }\end{array}$ & $\begin{array}{c}\text { Penalty } \\
\text { (KRW } \\
\text { mil.) }\end{array}$ \\
\hline 02 & $80 /$ top 6 & 51 & 245 & 5,667 \\
\hline 03 & $96 /$ mid-high 10 & 70 & 346 & 6,835 \\
\hline $\begin{array}{c}04 \\
\left(1^{\text {st }}\right. \\
\text { half })\end{array}$ & 84 / mid-low 12 & 57 & 1,096 & 4,531 \\
\hline $\begin{array}{c}04 \\
\left(2^{\text {nd }}\right. \\
\text { half })\end{array}$ & $101 /$ bottom 11 & 73 & 210 & 1,378 \\
\hline 07 & $30 /$ top 3 & 9 & 50 & 284 \\
\hline 08 & 30 / upper middle 4 & 8 & 11 & 142 \\
\hline $\begin{array}{c}09 \\
\left(1^{\text {st }}\right. \\
\text { half })\end{array}$ & $20 / 2^{\text {nd }}$ highest 2 & 15 & 18 & 230 \\
\hline $\begin{array}{c}09 \\
\left(2^{\text {nd }}\right. \\
\text { half })\end{array}$ & $20 / 2^{\text {nd }}$ highest 2 & 3 & 5 & 270 \\
\hline 10 & 31 / steel-related & 5 & 10 & 195 \\
\hline 11 & $63 / 6$ & 39 & 78 & 1,760 \\
\hline 12 & $350 / 7$ & 26 & 35 & 800 \\
\hline 13 & $328 / 6$ & 41 & 66 & 1,251 \\
\hline 14 & $251 / 6$ & 32 & 52 & 1,158 \\
\hline 15 & $288 / 9$ & 41 & 88 & 2,479 \\
\hline 16 & $162 / 6$ & 23 & 233 & 2,034 \\
\hline 17 & $383 / 23$ & 14 & 19 & 785 \\
\hline
\end{tabular}

Source: Korea Fair Trade Commission, Fair Trade White Paper 2011-2018 Note: From 2011, annual statistics are calculated by combining half-year results.

\section{Theoretical Justification of the Disclosure}

Previous section evidences that KFTC has carried out the disclosure regulation quite successfully. However, it hardly substantiates that those kinds of disclosure are so imperative that KFTC should intervene in information revelation. Even if KFTC can enforce the disclosure measures in efficient way and the violation rate is getting low, it does not mean that those disclosure measures are necessary.

Mandatory disclosure is a kind of governmental regulation which intends to correct "market failure." Where a market fails to function under some circumstances, government can be invited to resolve this "market failure" problem. What kind of "market failure" is mandatory disclosure supposed to correct? Hart (2009) demonstrates the presumable grounds on which mandatory disclosure by the government can be justified. Here we consider three possible justifications that are suspected to bear on KFTC's disclosure: (1) asymmetric information, (2) bounded rationality, (3) judgment proof, and (4) agency problem.

\subsection{Asymmetric Information}

Suppose there are two types of business groups. One is to allocate the resources within a group to maximize the total profit of all subsidiaries. This type of large groups belongs to the one that internal capital markets literature indicates (Brusco \& Panunzi, 2005; Shin \& Stulz, 1998; Stein, 1997). The other type of business groups is to transfer corporate resources on behalf of the controlling owner's private benefit (Johnson, La Porta, Lopez-de-Silanes, \& Shleifer, 2000). The problem of asymmetric information occurs where market participants, such as minor shareholders and debtors, are not able to know which one is which.

If compliance with the disclosure is not costly to the business groups, all information would be revealed voluntarily (Grossman \& Hart, 1980; Grossman, 1981; Milgrom, 1981). The former group maximizing total profits is willing to disclose all information voluntarily while the latter one seeking private benefits will hide unfavorable information. Voluntary disclosure reveals which one is of "good" type; thus, it indirectly reveals which one is of "bad" type-complete disclosure is achieved indeed. In this sense, the problem of this asymmetric information is solved by voluntary disclosure and mandatory disclosure is not needed at all.

Now we can reason that mandatory disclosure may be required only if substantial cost of information disclosure exists for the business groups. As of now, it is hard to evaluate how costly the disclosure measures are for the large business group, not for KFTC itself. Comparing the costs for the entire groups' disclosure and the benefits of screening out opportunistic business groups, we can determine whether KFTC's disclosure measures are indispensable regulation.

Current arguments for KFTC's regulatory disclosure lack a proper comparison of social costs and social benefits. Rather they maintain that KFTC's enforcement has been successful referring to the decline of violation rates (Table 2-4). Yet we remark that the validity of KFTC's disclosure as a remedy for asymmetric information must be evaluated not by the regulator's achievement but by the business groups' compliance cost.

\subsection{Bounded Rationality}

Neo-classical economic theory postulates that rational stakeholders could monitor business groups with due care. As a general consequence, Coase $(1937,1960)$ maintains that rational economic agents would make the efficient contract regardless of how they are endowed legal rights. It 
does not matter whether the Fair Trade Act makes a business group disclose the information or not. The most economically efficient disclosure will be discovered between rational stakeholders and the controlling owner/manager. In this sense, as long as the rationality assumption holds true, the mandatory disclosure does favor neither outside stakeholders nor business groups.

Bounded rationality theory, however, admits that people are not so rational that the initial guideline could help to find out a better solution (Thaler \& Sunstein, 2008). If minor shareholders or outside debtors lack invigilation due to bounded rationality, a "bad" business group might not be discernible even though it hides information on behalf of the controlling owner's private benefit. In this case, KFTC's mandatory disclosure makes stakeholders watch substantial information easily and the business groups internalize stakeholders' oversight.

This theory puts a reason for mandatory disclosure. Provided that the social cost of enforcing disclosure does not exceed the social benefit of preventing opportunistic behavior of large business groups, the mandatory disclosure would be of practical use under the circumstances of bounded rationality. Being that as it may, it falls on the empirical test whether the net benefit is greater than zero or not.

\subsection{Judgment Proof}

Business groups usually comprised of subsidiaries or affiliates under the same controlling manager. When the controlling manager infringes on a subsidiary's stakeholders, the harmed can claim the compensatory damage by lawsuit. Where the damage is beyond the corporation's total assets or the judgement holders are constrained by other legal restrictions, we define these cases “judgment proof” (Horack, 1918). Shavell (1986) insists that some criminal penalties should be charged on the manager individually, which are expected to hinder the manager's exploitation of judgement proof.

As shown in section 2, current Fair Trade Act does not levy criminal penalty on the responsible manager who is usually the controlling executive officer. Only civil sanctions such as fines or warnings are employed as corrective disciplines. It alludes that judgment proof is not the major concern for KFTC to conduct the mandatory disclosure of large business groups. Or the penalties of the Fair Trade Act might be insufficient to hamper the controlling owner/manager's opportunistic behavior in terms of preventing the judgment proof problem.

\subsection{Agency Problem}

A typical company in the U.S. is depicted by a stand- alone firm with a powerful CEO and a plethora of minor shareholders (Berle \& Means, 1932). Given this dispersed ownership, the manager is not likely to maximize the shareholders' interest but his own private benefit. It is called an 'agency problem' that leads to suboptimal firm value (Jensen \& Meckling, 1976). However, except for the U.S. and the U.K., most firms are run by the manager with small but significant shares (controlling minority shareholders). Utilizing complex cross-ownership or stock pyramids of subsidiaries, the controlling minority shareholder/manager is able to retain the ultimate control even with minor shares (La Porta et al., 1999; Bebchuk, Kraakman, \& Triantis, 2000).

Large business groups with controlling minority shareholders have somewhat different agency problem. Transferring corporate assets and business opportunities, the controller might pursue private benefit in sacrifice of other shareholders. This kind of problem is called 'tunneling' (Johnson et al., 2000). Examples are differential voting rights, self-dealing transaction, appropriation of corporate opportunity, high managerial compensation, and so on.

Current KFTA can be construed as a countermeasure to preclude 'tunneling' problem of large business groups. Disclosure of group status, important matters of privately held subsidiaries, large internal transactions informs the investors transparently. Especially the disclosure of important matters on privately held subsidiaries is a good example. KFTC stresses that the disclosure of private subsidiaries is for the minor shareholders of public subsidiaries. It implicates that investors in private firm may not protected but investors in public firm must be protected. That explains why KFTC's mandatory disclosure is needed.

\section{Conclusions}

Section 3 suggests four viable justifications for KFTC's current mandatory disclosure policy. Three hypotheses survive: Asymmetric information on compliance costs, bounded rationality of minor shareholders, and agency problem pertinent to 'tunneling.' Admittedly, to determine whether these hypotheses really account for the KFTC's mandatory disclosure, we need to further empirical tests. To date, there is a paucity of literature on empirical studies on mandatory disclosure (Leuz \& Wysocki, 2016). It would be hard to evaluate KFTC's mandatory disclosure until we discover rigorous methods to measure net benefit of the disclosure.

Despite the lack of evidence, we would like to suggest a few policy recommendations. First, 'tunneling' theory advises caution to excessive managerial compensation. Section 3.4 implicates that the controlling shareholder/ 
manger might take advantage of other stakeholders, especially minor shareholders, which is usually feasible by the complex corporate structure (La Porta et al., 1999; Bebchuk et al., 2000). KFTC's current disclosure measures are likely to detect illegal or improper asset transfers among the subsidiaries. However, excessive managerial compensation within the privately held firms is not subject to disclosure; whereas, the disclosure of the compensation of publicly traded firms is strictly enforced by the Capital Markets Act (Gwon, 2015, 2018; Gwon \& Moon, 2019). To prevent the tunneling problem mentioned by Johnson et al. (2000), KFTC should pay equal attention to publicly and privately traded firms in terms of executive compensation.

Second, domestic business groups should be forced to disclose the information on their foreign subsidiaries. When it comes to computing total assets (Table 1), the statistics of only domestic subsidiaries are aggregated since collecting information on foreign subsidiaries or affiliates is extraterritorial-KFTC's disclosure measures and compliance inspections are applied and enforced within South Korean jurisdiction. KFTC's inability of obtaining correct information on foreign subsidiaries might aggravate the problem of asymmetric information, bounded rationality, and agency problems. To prevent overseas 'tunneling' problem, the controlling manager is required to report foreign subsidiary status truthfully and KFTC must be authorized to charge criminal penalties to the controlling manager unless $\mathrm{s} / \mathrm{he}$ reports it truthfully. Even though KFTC or the Korean courts are not able to investigate the authenticity, they may be able to find it later presumably cooperating with foreign regulators or whistle blowers.

\section{References}

Bebchuk, L. A., Kraakman, R., \& Triantis, G. (2000). Stock pyramids, cross-ownership and dual class equity: The mechanisms and agency costs of separating control from cash-flow rights. In R. K. Morck (Ed.), Concentrated Corporate Ownership(pp.445-460), University of Chicago Press.

Berle, A. A., \& Means, G. C. (1932). The modern corporation and private property. New York, Macmillan Publishing Co.

Brusco, S., \& Panunzi, F. (2005). Reallocation of corporate resources and managerial incentives in internal capital markets. European Economic Review, 49(3), 659-681.

Coase, R. H. (1937). The nature of the firm. Economica, 4(16), 386-405.

Coase, R. H. (1960). The problem of social cost. Journal of Law and Economics, 3(1), 1-44.

Grossman, S. J. (1981). The informational role of warranties and private disclosure about product quality. Journal of Law and Economics, 24(3), 461-483.

Grossman, S. J., \& Hart, O. D. (1980). Disclosure laws and takeover bids. Journal of Finance, 35(2), 323-334.

Gwon, J. H. (2015). A strategic effect of bundling on product distribution. Journal of Distribution Science, 13(10), 15-21.

Gwon, J. H. (2018). Broker-dealer competition in the Korean financial securities markets. International Journal of Industrial Distribution \& Business, 9(4): 1926.

Gwon, J. H., \& Moon, B. (2019). Executive compensation in Korea: Evidence from a new mandatory disclosure. Journal of Asian Finance, Economics and Business, 6(3), 91-101.

Hart, O. D. (2009). Regulation and Sarbanes-Oxley. Journal of Accounting Research, 47(2), 437-445.

Horack, H. (1918). Insolvency and specific performance. Harvard Law Review, 31(5), 702-720.

Jensen, M. C., \& Meckling, W. H. (1976). Theory of the firm: Managerial behavior, agency costs and wwnership structure. Journal of Financial Economics, 3(4), 305360.

Johnson, S., La Porta, R., Lopez-de-Silanes, F., \& Shleifer, A. (2000). Tunneling. American Economic Review, 90(2), 22-27.

La Porta, R., Lopez-de-Silanes, F., \& Shleifer, A. (1999). Corporate Ownership Around the World. Journal of Finance, 54(2), 471-517.

Leuz, C., \& Wysocki, P. D. (2016). The economics of disclosure and financial reporting regulation: Evidence and suggestions for future research. Journal of Accounting Research, 54(2), 525-622.

Milgrom, P. (1981). Good news and bad news: Representation theorems and applications. Bell Journal of Economics, 12(2), 380-391.

Shavell, S. (1986). The judgment proof problem. International Review of Law and Economics, 6, 45-58. 